\title{
吸引ポンプによる静電気の分析と検討 ポリエチレン製熱交換器付人工肺について—
}

\author{
武田正則 小林史枝 渡辺 猛 佐藤正啺 杉山賢司
}

\begin{abstract}
【要旨】ポリエチレン製の熱交換器付人工肺と送血に遠心ポンプを使用した症例で, 温度プローブ および患者の頭部に接触した際に強力な電撃を経験した。これは, 吸引ポンプによる静電気が関与 したと考えられ，带電状況について分析検討した。実験的に人工肺と吸引回路内を生理食塩水で満 たし, 吸引用ローラポンプの回転数を 50 ～ $250 \mathrm{rpm}$ と変化させたとき, 生理食塩水への帯電電位は $800 \sim 2,200 \mathrm{~V}$ であった。また，回転数 $150 \mathrm{rpm}$ に扔ける帯電電位は，時間とともに上昇し， 5 分間 で $1,500 \sim 2,100 \mathrm{~V}$ と最高值に達し, 維持された。ポリエチレン製の熱交換器は, 絶緑素材のため熱 交換器に供給される水と血液の間に電気的回路ができず，静電気が血液に帯電し，患者接触時に電 撃を感じる場合がある。臨床例では, リザーバと患者の頭部などで最高 $2,500 \mathrm{~V}$ が測定された症例 を経験した。電撃は，物品などを落としたりする 2 次的災害を引き起こしたり，大気の冷温乾燥な ど条件によっては,より帯電電位が上昇し, 熱交換器の絶縁破壊 $(1.8 \sim 2.3 \mathrm{kV})$ を引き起こす可能性 がある。そのため, 静電気が带電しないような熱交換器の改善または対策が必要と考えられた。
\end{abstract}

Key words : ポリエチレン製, 静電気, 带電電位, 電気的回路, 電撃

\section{I 。緒 言}

送血用ローラーポンプは，チューブとの摩擦によ り静電気を発生することが知られており,心電図モ ニタなどに雑音障害を起こすことがある。一方, 吸 引用ローラーポンプの影響については，血液流量が 少ないためか, あまり重要視されていなかった。し かし，生体適合性に優れたポリオレフィン製やポリ エチレン製の熱交換器付人工肺を使用した場合に, 遠心ポンプで送血を行ったにもかかわらず，患者へ の接触時に電撃を経験した。これは，吸引用ローラ 一ポンプによる高電位な静電気によるものと考えら れ, 今回, 模擬人体実験回路を製作し, 吸引用ロー ラーポンプによる静電気の発生電位と帯電状況を分 析検討したので報告する。

II. 方 法

\section{1. 実験装置}

模擬人体実験回路は, 生理食塩水 $3,000 \mathrm{cc}$ を容器 へ満たし，ローラーポンプで吸引し静脈リザーバを 経て, 遠心ポンプで熱交換器付人工肺に送り容器へ 戻す方式とした(図 1 )。また，ローラーポンプは, ヨストラ製で, ポンプヘッドチューブにはタイゴン の $1 / 4$ インチを使用した。静電気の測定器は, 振動 式表面電位検出方式の静電気電位監視装置 (春日電

\footnotetext{
・三井記念病院 MEサービス部
}

機社製)を使用し, 带電電位は容器水面上にて計測し た。

\section{2. 摩擦静電気発生の確認}

吸引用ローラーポンプとチューブ摩擦による静電 気発生を確認するため, 回転数を $20 \mathrm{rpm} に$ 設定し, 人工肺の温度プローブと接地間において摩擦静電気 波形を低電圧計で観察した。

\section{3. 回転数と時間的な電位变化}

回転数の変化による带電電位 (回転数を変化させ る前に帯電した静電気は接地にて 0 にし, 10 分間は 回転数を一定にした時点の電位を測定) と回転数を $150 \mathrm{rpm}$ 一定にし, 吸引回路内を生理食塩水で満た された状態での帯電電位の時間的变化を 8 回 $(8$ 日 間)計測した。

4. 静電気と温度について

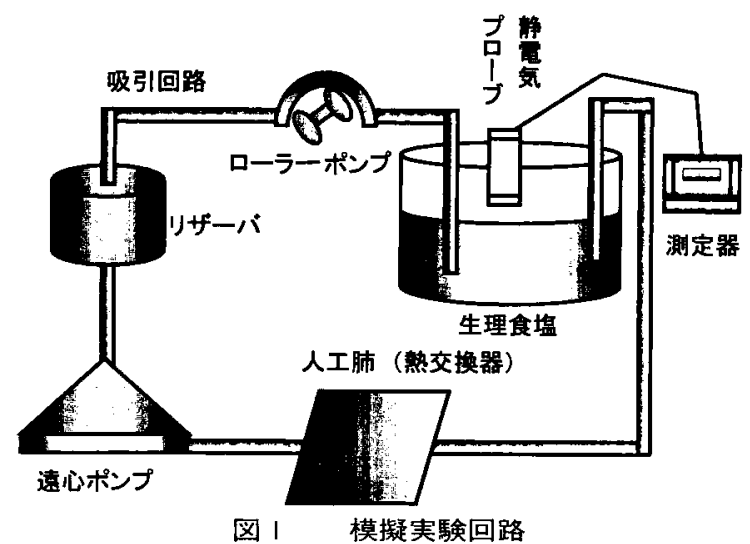


静電気と温度の関係を調査するため, 液温を 20 , $30,40^{\circ} \mathrm{C}$ 変化させたときの室温 20 および $25^{\circ} \mathrm{Cに}$ おける帯電電位を 5 回 ( 5 日間) 測定した。

\section{5、踟床的な条件での計測}

ローラーポンプの回転数を $150 \mathrm{rpm}$ 一定にし, 吸 引回路の先端を液中から 5 秒間隔で引き上げ，チュ 一ブ内を空気混入状態にして, 帯電電位の時間的変 化を 8 回 ( 8 日間) 測定した。

6. 症例等十測

症例に扔ける計測は，静脈血リザーバの側面と患 者の顔面皮间(額)上にて帯電電位を測定した。また， ステンレス製の熱交換器付人工肺についても計測し た。

\section{III. 結 果}

吸引用ローラーポンプ(2 ローラー)の回転数を $20 \mathrm{rpm} に し た$ 状態で, 人工肺の温度プローブと接地 間の電圧波形観察は 1 分間に 40 回の微小電圧変化 $(0.2 \mathrm{~V})$ を示し，ローラーによる摩擦静電気の発生

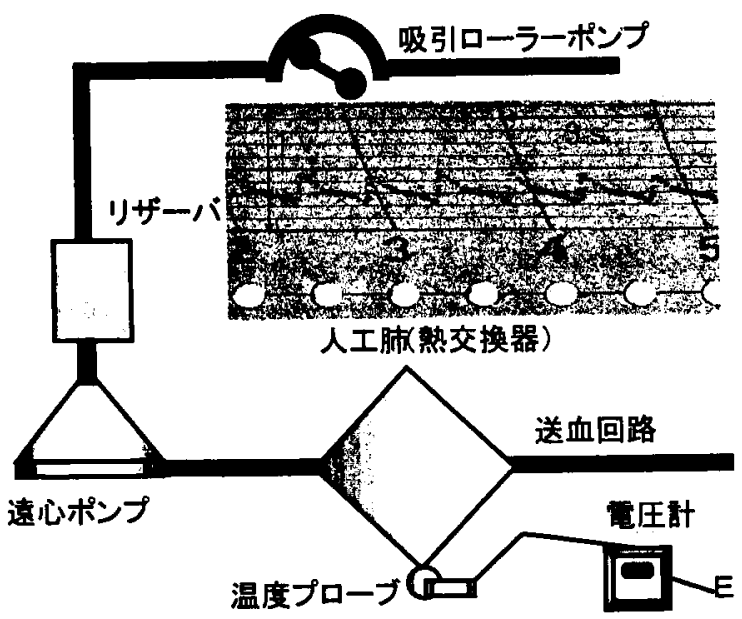

図 2 吸引ポンプによる静電気波形

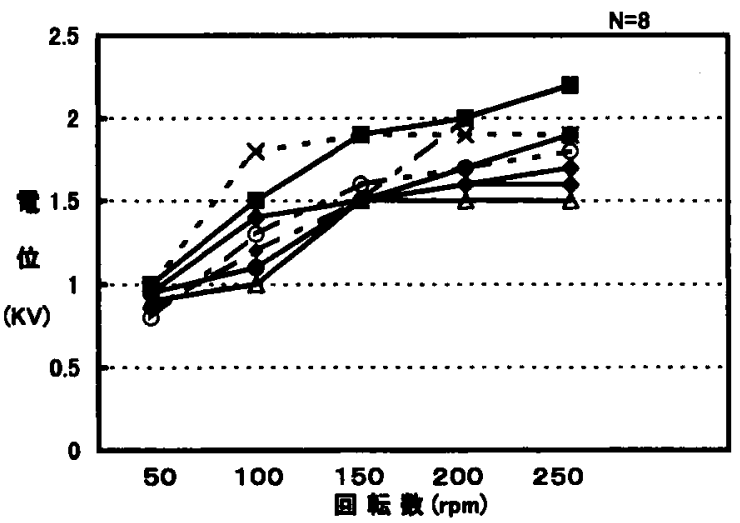

图3回転数による带㽢位の变化
表 | 液温・室温と帯绳電位の闑係

\begin{tabular}{|c|c|c|}
\hline 洨温至温 & $20^{\circ} \mathrm{C}$ & $25^{\circ} \mathrm{C}$ \\
\hline $20^{\circ} \mathrm{C}$ & $24 \sim 1.6 \mathrm{kV}$ & $2.2 \sim 1.7 \mathrm{kV}$ \\
\hline $30^{\circ} \mathrm{C}$ & $21 \sim 1.5 \mathrm{kV}$ & $1.7 \sim 1.5 \mathrm{kV}$ \\
\hline $40^{\circ} \mathrm{C}$ & $1.6 \sim 1.1 \mathrm{kV}$ & $1.3 \sim 1.0 \mathrm{kV}$ \\
\hline
\end{tabular}

が確認された（図 2 )。

回転数による帯電電位は, $150 \mathrm{rpm} て$ 1,500 1,900 V を示した後, 200 および $300 \mathrm{rpm} て ゙$ は顕著な上昇は認められなかった（図 3 )。

$150 \mathrm{rpm}$ における带電電位は，時間とともに上昇 し, 5 分間程度で $1,500 \sim 2,100 \mathrm{~V}$ と最高に達し維持 された(図 4)。

吸引回路に生理食塩水と空気を交互に入れたとき (吸引用ローラーポンプの回転数は $150 \mathrm{rpm}$ 一定) の時間的な帯電電位変化は, 7 分間で 1,500〜2,000 $\mathrm{V}$ の最高值を計測し，多少の空気混入においても静 電気の発生は引き起こされることが判明した(図 5 )。

また, 液温と室温の変化による帯電電位は, 回転 数 $150 \mathrm{rpm}$ 一定条件で, 液温室温ともに低温におい

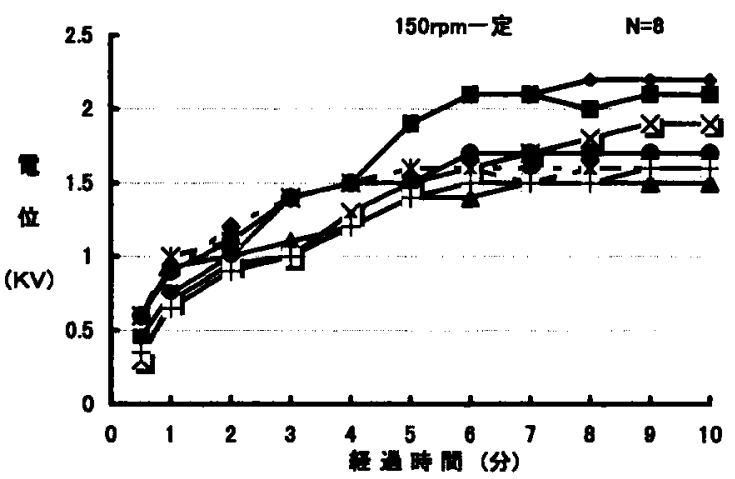

図 4 帯電軋位の時間的密化

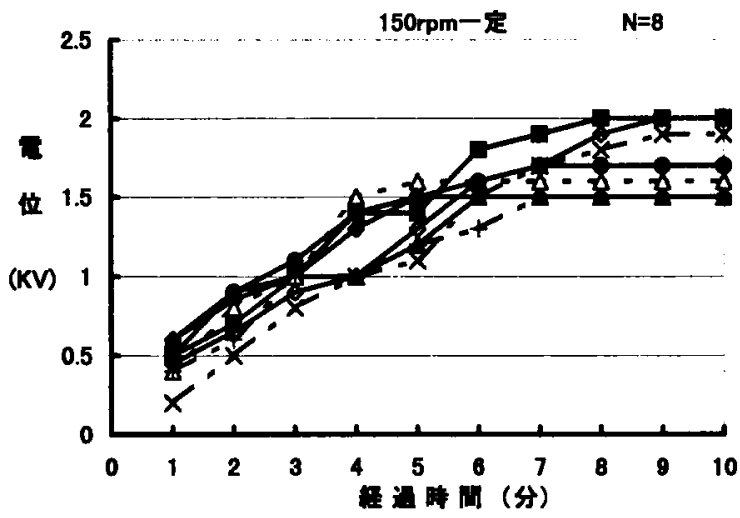

図 5 空気混入㭙の时的变化 


\begin{tabular}{lcrr}
\hline 症例 & 熱交換器* & リザーバ & 患者頭部 \\
\hline CABG & $\mathrm{P}$ & $1.3 \mathrm{kV}$ & $0.8 \mathrm{kV}$ \\
$\mathrm{MVR}$ & $\mathrm{P}$ & $2.5 \mathrm{kV}$ & $1.6 \mathrm{kV}$ \\
$\mathrm{AVR}$ & $\mathrm{P}$ & $2.1 \mathrm{kV}$ & $1.2 \mathrm{kV}$ \\
$\mathrm{CABG}$ & $\mathrm{S}$ & $0 \mathrm{~V}$ & $0 \mathrm{~V}$ \\
$\mathrm{MVR}$ & $\mathrm{S}$ & $0 \mathrm{~V}$ & $0 \mathrm{~V}$ \\
\hline
\end{tabular}

* P：ポリエチレン製 $\mathrm{S}$ : ステンレス製

て高值を示した(表 1)。

臨床症例においいては，リザーバ側面と患者の頭部 上にて $1,200 \sim 2,500 \mathrm{~V}$ の带電電位が計測され，ス

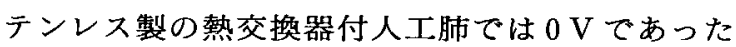
(表 2 )。

\section{IV. 考 察}

1990 年頃から,ローラーポンプによる摩擦静電気 の心電図に対する雑音障害が問題になっだ”。心電 図への雑音障害は, 心蔵の正確なりズムを把握でき ず，心電図観察に影響を及ほす結果となった2)。ま た, 1997 年には, 熱交換器にポリオレフィン素材 (非 電導性)を使用した人工肺に扔いて, 静電気の影響で 熱交換器リークが発生した。この調査では, 送血ポ ンプに遠心ポンプとローラーポンプヘッドにシリコ ン材を使用した場合は影響なく，塩化ビニール製の ポンプヘッドにおいては, 熱交換器リークの発生す る恐れが示唆された ${ }^{3)}$ 。しかし, 我々はポリエチレン 素材の熱交換器付人工肺での体外循環中, 送血に遠 心ポンプを使用していたにもかかわらず，人工肺の 温度プローブ装着部と患者の頭部に接触した際, 強 い電撃を経験した。当初, 人工心肺装置か冷温水供 給装置の漏れ電流を疑ったが, 冷温水供給装置の電 源を切っても発生に影響なく, 吸引用ローラーポン プを停止するかポンプヘッドに水を振り掛けたとき， 電撃が消滅したことにより静電気の影響であること を疑った。

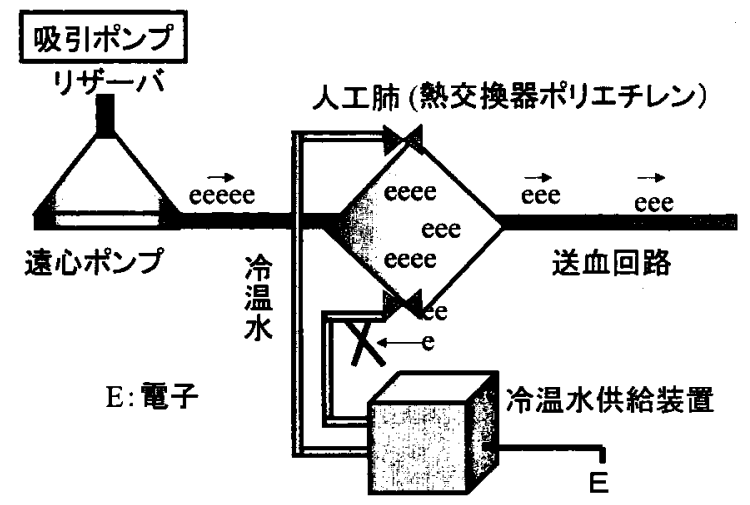

図 6
そこで，今回我々は，吸引用ローラーポンプによ る静電気の分析を実施した。吸引用ローラーポンプ とチューブの摩擦による静電気発生の確認計測では, $20 \mathrm{rpm}$ で電压波形変化が 40 サイクルであった。ポ ンプは 2 ローラーであり, 電圧変化は回転数の 2 倍 のサイクルとなったことにより摩擦電気が確認され た。

吸引用ローラーポンプの回路内には常時血液が充 満していることはないため, 臨床的な条件を想定し た血液と空気を混入した実験も施行したが，7分以 上経過すれば, $1,500 〜 2,000 \mathrm{~V}$ の帯電電位が観測さ れた。実験では, 2,200 V以上の帯電電位を計測する ことはなく，実験回路装置の絶縁状態による帯電の 限界ではないかと考える。

近年，ステンレスより生体適合性に寄与している ポリエチレン・ポリウレタン・ポリオレフィンなど を素材とした熱交換器付人工肺が市販されている。 これらの人工肺を使用した場合, 我々の実験からは 吸引用ローラーポンプによる摩摖静電気は熱交換器 の素材により冷温水供給装置から接地へ流れること ができず，血液および患者体内に高電位の静電気が 帯電することが推測される(図 6)。

また，心電図に対する静電気の影響が多く出現す るのは, 冷温で乾燥時期であると言われており 我々の実験においても低い室温の場合に帯電電位が 高かったことが確認された。ステンレス製の熱交換 器付人工肺では, 熱交換器に供給される水と血液の 間に電気回路ができ，高電位は接地側に流れる。冷 温水供給装置に使用される水道水の抵抗率は約 10 $\Omega \mathrm{m}$ であり", 不純物が少なければ，かなりの高抵抗 となる。このため, 完全に接地側に流れることがで きず，血液と体内に带電する場合があり，心電図へ の雑音障害を招くものと考える。

日本国内では湿度が高く, 熱交換器の破壊を引き 起こすような電位は帯電しないかもしれないが, 高 分子材料などの絶縁破壊電圧は $24 \sim 30 \mathrm{KV} / \mathrm{mm}$ と 言われて抢り ${ }^{5,6)}$, 熱交換器に使用されている素材の 肉倡は 75〜100 $\mu \mathrm{m}$ で, $1.8 \sim 2.3 \mathrm{KV}$ 以上の帯電で 絶縁破壊が発生する場合がある7。我々の実験によ ると最高で $2.2 \mathrm{KV}$ の帯電電位を計測しており，患 者の絶縁状態と冷温乾燥条件が整えば熱交換器の素 材が絶縁破壊を引き起こし，リークする恐れがある。 また，リークしない場合でも，電撃により物品を落 としたりする 2 次的災害が発生する可能性がある。

対策として一部の製品は, 熱交掺器の血液と供給 水の間に金属材を挿入することにより電気的回路を 作り，対処している場合もある7が，コストが高価と なる。そのほかに吸引ポンプヘッドチューブをシリ コン材にするか, ポンプの 2 次側に金属コネクタを 装着して接地するか温度プローブを接地したりする 
方法もあるが，すべて一時的で，根本的な対策では ない。吸引にローラポンプを使用しないで陰圧で行 う方式を採用している施設もある。この場合には， 静電気は発生しないが, 空気の混入が多くなったり, 流量調整が困難であり，操作性と安全性に問題があ る ${ }^{8)}$ 。今後, より生体適合性の優れた素材を選択して いくことは重要であるが，ステンレス材による熱交 換器との生理的な比較においても顕著な有意差は見 受けられないため ${ }^{9,10)}$, 素材の見直しを検討する必要 があると考えられた。

\section{V. 結 語}

ポリエチレン製の熱交換器付人工肺において, 吸 引用ローラーポンプによる静電気の分析と検討をし た。その結果, 非電導性素材を用いた熱交換器付人 工肺は, 吸引用ローラーポンプにより発生した静電 気が血液と人体に高電位で帯電する可能性があり, 臨床使用に際しては注意を要する。また, 安全性向 上のため, 対策と更なる改良が必要と考える。

\section{- 参考文献}

1) Alvin Wald, Ph. D. : Plastic induced ECG interference on Cardiopulmonary bypass ; An Adventure in clinical Engineering. Journal of Clinical Engineering, 304-424, 1990.

2 ) 小池竜平：ローラポンプと静電気ノイズ. Clinical Engineering, 13(11); 784-785, 1992.
3 ) R. J. Elgas, J. M. Binford, N. D. Plotkin, et al. : The roller pump as a source of electrostatic energy in an extracorporeal circuit ; Cardiovascular Engineering, 1997. p. 222-223.

4 ) 赤尾保男 : 環境電磁工学の基礎. 初版, 東京, 電子 情報通信学会. 1991. p. 45-47.

5) Hoshang J. Khambatta, J. Gilbert Stone, Alvin Wald. et al. : Electrocardiogrphic artifacts during cardiopulumonary bypass ; Anesth analg, 71 ; 8990, 1990.

6 ) 田中謙一郎, 村田愛祐共著：電気の理論 I . 初版, 東京，オーム社. 1970. p. 33 .

7 ) Jos Snijders, Peter de Bruijin, Marcel Bergmans. et al. : Study on causes and prevention of electrostatic charge build-up during extracorporeal circulation. Perfusion, 14 ; 369-370, 1999.

8 ) 広浦 学, 仲畑和彦, 川村光生, ほか: 吸引式体外 循環法における人工肺への空気吸い込みに関する検 討. 体外循環技術，24(3)；47-48, 1998.

9 ）赤城治彦, 高野久輝, 阿久津哲造：新しい外部潅流 方式膜型人工肺 HF-5000 の性能検定. 人工蔵器, 19 (1)；586-588, 1990.

10）川脇雄次, 重光 修, 葉玉哲生: 外部潅流方式 hollow fiber 型人工肺 HF-5000 およびMAXIMA 肺の 臨床的比較. 体外循環技術, 17(2)；36-37，1991. $\left.\begin{array}{l}\text { 本論文は，第 } 25 \text { 回日本体外循環技術研究会大会にて } \\ \text { 報告した。 }\end{array}\right]$ 